\title{
OBITUARIES
}

\section{Prof. C. van Riet Lowe}

The death of Prof. C. vas RIET Lowe in Johannesburg, South Africa, on June 17 is a severe loss to archæology not only in South Africa but also to the science as a whole.

Prof. van Riet Lowe trained as a civil engineer at the University of Cape Town, but interrupted his studies to serve with distinction in the First World War, first with the South African Artillery and later with the Royal Horse Artillery, in East Africa, Egypt, Palestine, Italy and France. In 1940 he again donned uniform to take command of the Witwatersrand University Training Corps Battery.

In 1920 he entered the Civil Service as an engineer in the Public Works Department and reached the top of his profession in 1931, when at the age of thirty-seven he became chief engineer of the Department.

During 1923-28 he was in charge of bridge construction in the Orange Free State. He was quick to seize the opportunities this presented for archæological field-work in his spare time. He discovered a large number of Stone Age sites, began the long series of research publications which at the time of his death exceeded 130, and rose rapidly to the forefront of South African archæologists. In 1929 he collaborated with Prof. A. J. H. Goodwin in publishing "The Stone Age Cultures of South Africa", which still is the most comprehensive account of South African prehistory.

In 1935 the Government established the Bureau of Archæology, which later became the Archæological Survey of the Union of South Africa, and van Riet Lowe was the obvious choice as its first director. The University of the Witwatersrand provided accommodation for the new. institution and appointed the director to a chair of archæology. At this time, too, the Commission for the Preservation of Natural and Historical Monuments, Relics and Antiques was reconstituted under a new Act of Parliament, and Prof. van Riet Lowe became a member and secretary of that body. He was thus entrusted with building up these new institutions from their beginnings and acquitted himself of all th:ee tasks with great distinction.

Prof. van Riet Lowe's contributions to archæology cannot be reviewed in a brief note. One of his first projects as director of the Archæological Survey was a geological and archæological study of the gravels of the Vaal River, undertaken jointly with the Geological Survey of the Union, which for the first time gave us a climatic sequence and cultural correlation in the south of the continent. A similar study of the Little Caledon River has just been published. He directed the important excavations at Mapungubwe undertaken by the University of Pretoria, and the excavation of the Cave of Hearths in the Makapan's Valley, which proved to contain a complete Stone Age sequence from the end of the Earlier Stone Age to modern times.

$\mathrm{He}$ was assiduous in recording and studying the great wealth of prehistoric art which adorns the South African rock shelters, on which he became the leading authority, and welcomed the collaboration of the Abbé Breuil, who was invited by the late General Smuts to join the staff of the Archæological Survey during the Second World War.
Van Riet Lowe travelled widely in the pursuit of his researches. In 1931, when he represented the South African Association for the Advancement of Science at the centenary meeting of the British Association, he made a study of the important archæological collections in England and France and visited many sites in company with such authorities as Burkitt, Henry Balfour, Breuil, Harper Kelley and Henri Martin. In 1937 he undertook a long journey of archæological exploration through Egypt and the Sudan, East Africa, the Belgian Congo and the Rhodesias, and two years later was invited by the Government of Uganda to describe the prehistory of that important territory in collaboration with Mr. E. J. Wayland. This work was published as Part 2 of a memoir of the Geological Survey of Uganda; Part 1 on the Quaternary geology of the area, by Mr. Wayland, is in preparation. He twice paid official visits to Mozambique to advise the Government of that territory on the organization of archæological research and the preservation of monuments.

His long service in many spheres brought him many honours. He was a past president of the South African Association for the Advancement of Science, the South African Archæological Society and the South African Museums Association. He was awarded the South Africa Medal by the South African Associa. tion for the Advancement of Science in recognition of his distinguished research, and the medal of the Historical Monuments Commission for his work in that field. He received the degree of D.Sc. from the University of Cape Town and was a Fellow of the Society of Antiquaries and the Royal Society of South Africa. He represented the Government of South Africa on the International Historical Monuments Commission of the League of Nations and later became a member of the International Commission on Monuments of Unesco. He took an active part in the Pan-African Congresses on Prehistory in Nairobi, Algiers and Livingstone and was invited by the Governments of Iraq and Spain to visit their countries.

\section{Dr. C. E. Eddy}

Cecrl ERnest Edoy, whose death at the age of fifty-six following a heart attack has been reported from Perth, Western Australia, was one of Australia's best known and best loved scientists. Born in Albury, in New South Wales, he crossed the State border and was educated in Victoria at Colac High School and the University of Melbourne, from which ultimately he received the degree of D.Sc. However, it was to the whole of Australia that Eddy's services were rendered as director of the Commonwealth $\mathrm{X}$-ray and Radium Laboratory since 1935.

Following graduation, he took the M.Sc. degree at Melbourne in 1924 and became research physicist in the Department of Natural Philosophy in 1927. In 1927, also, he was awarded a Rockefeller Fellowship, and studied in England during 1927-28. Cambridge, as was to be expected, left its mark on him, as on many great figures in the world of physics. It is worthy of note that by 1929 Eddy was reporting the use of the Geiger counter for the detection of $\beta$-rays transmitted by aluminium. In the next few years, in collaboration with his chief, Prof. T. Laby, he 
published in the Proceedings of the Royal Society papers on the analysis of materials by means of $\mathrm{X}$-ray emission spectra.

In the 1930's and 1940's Eddy was a not infrequent contributor of articles to the British Journal of Radiology. From these can be deduced not only his native interest in the fundamentals but also his administrative acts in introducing methods of modern dosimetry into the Australian practice of radiology.

Indeed, as a scientific administrator, Eddy was outstanding. His battles to bring all that was best in the world to his own country will probably only be known and appreciated there. But in recent years he was to become more widely known in international scientific relations. With the introduction after the Second World War of radioactive isotopes, it fell to Eddy to negotiate abroad for materials and equip- ment with which Australian physical, biological and medical research could keep in step with the most advanced countries of the world. In the field of personal and public protection against radiations and radioactivity he was an active participant in the deliberations of the International Commission on Radiological Protection, and lately he had represented his country on the committee of the United Nations Organization called on to evaluate the world problem of radioactivity. Of this notable body he was elected chairman; his loss at this stage, after such a successful start of this Committee's deliberations, will be deeply felt.

In addition to his memibership of Australian scientific societies, Eddy was a Fellow both of the Physical Society and the Institute of Physics in Britain.
J. F. Loutit

\section{NEWS and VIEWS}

\section{Geology in Edinburgh :}

Prof. Arthur Holmes, F.R.S

Prof. Arthur Holmes, who shortly retires from the regius chair of geology in the University of Edinburgh, has been distinguished for his contributions in two main fields of his science. In his early days at the Imperial College of Science and Technology, London, his association with Lord Rayleigh led him to pioneer the investigation of the geological implications of radioactivity. Major contributions to the problem of the age of the Earth and to the assessment of the Earth's thermal history have come from his pen; for example, he first directed attention to the importance of potassium as an emitter of radiothermal energy. It is not too much to say that his work revolutionized previous conceptions of geological time and of the history of the Earth. At the same time, he continued the interest in igneous petrology first manifested in his account of his explorations in Mozambique with a series of outstanding studies which have included such diverse subjects as the alkaline igneous rocks of North-west Angola, the Arctic basalts, the Whin Sill and the North of England dykes, the petrography and chemistry of the potash-rich lavas of Uganda, and the origin of kimberlite. He has never been content with mere petrographical description; through all his work there has run the search for a fundamental mechanism capable of producing the diversity of rock types which the Earth's crust exhibits, leading him far in the direction of syntexis and metasomatism under the influence of emanations.

In 1924, Holmes went to Durham as first head of the newly founded Geology Department; there he remained until his translation to Edinburgh in 1943. His great gifts as a teacher and his lucid text-books on petrography and physical geology have made his influence on the science profound and lasting. His later years have been full of honours; he was elected to the Royal Society in 1942 ; a foreign member of the Royal Swedish Academy of Sciences and of the Royal Netherlands Academy of Science in 1947 and of the Paris Academy of Sciences in 1955. This year he received the Wollaston Medal, senior award of the Geological Society of London, and is to be the recipient of the Penrose Medal of the Geological Society of America.
Prof. F. H. Stewart

Dr. F. H. STEWART, senior lecturer in geology in the Durham Colleges, is to succeed Prof. Holmes in Edinburgh. An Aberdonian, Dr. Stewart was educated at Fettes College, Edinburgh, and in the University of Aberdeen, where in 1937 he gained a first-class honours B.Sc. in geology. Having been awarded the Kilgour Research Studentship, he commenced investigations of igneous petrology under Prof. T. C. Phemister; these he continued at the Department of Mineralogy and Petrology at Cambridge under Prof. C. E. Tilley during 1939-41. He was then appointed to the physico-chemical research establishment of Imperial Chemical Industries at Billingham. Here he became interested in the potashbearing salt deposits, and began his studies on the cores of Eskdale No. 2 borehole, the first boring to find potassium evaporites in Britain. In 1943 he was appointed lecturer in petrology in the University of Durham, and here the work begun in Scotland and at Billingham has been brought to fruition.

Dr. Stewart is chiefly known in the field of igneous petrology for his study of the layered basic complex of Belhelvie, probably the best example in Britain of a type which includes also the great Bushveld body in South Africa. After completing this work, he began a revision of part of the Tertiary volcano of Skye, which is still in progress. His contributions to the petrological study of the saline deposits have been many and varied, but they have served especially to reveal the numerous and complex mineral substitutions which have taken place in the evolution of potassium-rich zones. The publication of his work on the borings undertaken for Messrs. Fisons around Robin Hood's Bay, Yorkshire, is awaited with much interest. In the meantime, Dr. Stewar's petrological investigations have found recognition in the award of a moiety of the Lyell Fund, by the Geological Society of London in 1951, and of the Mineralogical Society of America Award for 1952. In following Arthur Holmes from Durham to the Edinburgh chair, Frederick Stewart takes with him a broadly-based reputation in mineralogy and petrology; but these subjects do not represent the sum of his interests. His enthusiasm for field geology in all its aspects, his skill as a collector of fossil fishes and his knowledge of ornithology reveal him as a naturalist in the best sense. 